\title{
Trans-Atlantic genetic uniformity in the rare snowbed sedge Carex rufina
}

\author{
Kristine Bakke Westergaard • Inger Greve Alsos • \\ Torstein Engelskjøn • Kjell Ivar Flatberg • \\ Christian Brochmann
}

Received: 23 August 2010/ Accepted: 6 April 2011/Published online: 1 May 2011

(C) The Author(s) 2011. This article is published with open access at Springerlink.com

\begin{abstract}
The red-listed, amphi-Atlantic sedge Carex rufina is highly specialized to certain alpine snowbeds, and threatened by current changes in snow cover duration and moisture conditions. Here we address its range-wide genetic diversity, history, and conservation using amplified fragment length polymorphisms (AFLPs). Despite extensive primer testing, we detected very low overall diversity (4.1\% polymorphic markers). Only a single AFLP phenotype was found throughout Norway and across the Atlantic to Iceland and Greenland, while another was found in Canada, suggesting glacial survival in one East and one West Atlantic refugium. East Atlantic C. rufina has probably been heavily bottlenecked in a small refugium, possibly situated within the maximum limits of the ice sheets. Its lack of diversity is likely maintained through local clonal growth causing longevity of genotypes. Habitat availability appears as the main limiting factor for $C$. rufi$n a$, and its currently occupied habitats need to be preserved to ensure its long-time survival.
\end{abstract}

Keywords AFLPs - Amphi-Atlantic disjunction · Conservation · Fragmented populations - Snowbeds

K. B. Westergaard $(\bowtie) \cdot$ I. G. Alsos · T. Engelskjøn

Troms $\varnothing$ University Museum, University of Troms $\varnothing$, 9037 Troms $\varnothing$, Norway

e-mail: Kristine_w@ hotmail.com

K. B. Westergaard · C. Brochmann

National Centre for Biosystematics, Natural History Museum, University of Oslo, P.O. Box 1172, 0318 Blindern, Oslo, Norway

K. I. Flatberg

NTNU Museum of Natural History and Archaeology,

7491 Trondheim, Norway

\section{Introduction}

Snowbeds are particularly vulnerable to the ongoing changes in land use and climate, and plant species highly specialized to snowbeds are likely to be negatively impacted (ACIA 2005; Björk and Molau 2007; Granmo 1993; Schöb et al. 2009; Theurillat and Guisan 2001). Arctic-alpine vegetation is heterogeneous even at small spatial scales, because the prevailing winds result in patchy and recurring patterns of snow accumulation due to local topographic gradients, and thus variable distribution of moisture and duration of the growing season. Snowbeds are therefore naturally fragmented habitats, characterized by a long-lasting snow cover and low soil temperatures during a short growing season (e.g., Gjærevoll 1956). Climate warming results in earlier and complete thawing of snowdrifts, less moisture, and higher growth season temperatures; thus reducing the spatial extent of snowbeds, and increasing the fragmentation of specialized snowbed plants.

The short growing seasons in snowbeds are hypothesized to select for high selfing ability in snowbed plants (Scheffknecht et al. 2007). Selfing combined with habitat fragmentation make populations of snowbed species vulnerable to reduced gene flow and increased genetic drift and inbreeding (Frankham et al. 2010). Persistence of specialized snowbed plants, following further fragmentation of snowbeds due to environmental changes, will depend on their abilities to adapt to changing conditions based on their standing genetic diversity, and on their effective dispersal abilities.

After the last glaciation $(\sim 110,000-10,000$ years BP $)$, arctic-alpine plant species experienced large latitudinal range shifts during colonization of the North Atlantic region, which influenced their genetic structure and diversity in various ways. Some species were able to maintain high 
levels of genetic diversity because they expanded broadfrontedly into the previously glaciated areas (Alsos et al. 2009; Eidesen et al. 2007). Others experienced repeated bottlenecks leading to reduced genetic diversity in the entire region, as populations were successively founded by a few individuals (leading-edge colonization; Ehrich et al. 2007; Schönswetter et al. 2006). Although long-distance dispersal now is acknowledged as an important and relatively frequent migration process in plants (Alsos et al. 2007; Nathan 2006), it may be difficult for long-distance immigrants of pioneer species to establish and contribute to a gene pool once an area is already colonized (Hewitt 1999). Thus, plant species having highly disjunctive ranges and fragmented populations today may display a strong genetic structure due to restricted gene flow.

For many arctic-alpine plant species studied to date, the source regions for colonization of the North Atlantic region are inferred to be in the east or south (e.g., in the Alps; Schönswetter et al. 2003). However, some 30 amphiAtlantic disjuncts are absent from the Alps, as well as from areas to the east of the last ice sheets (the west-arctic species; e.g., Nordal 1987). These species have been central in a century-long debate concerning possible in situ glacial survival in northern Europe. This Greenlandic/North American element in the Scandinavian flora has its current European occurrence confined to previously glaciated areas. The
European distribution can alternatively be explained by in situ glacial survival, postglacial colonization from North America, or postglacial colonization from a central or eastern European refugium where populations subsequently went extinct. The main argument in favour of the in situ glacial survival hypothesis has been the lack of specialized adaptations for long-distance dispersal in these species (for a review, see Brochmann et al. 2003).

Here we focus on Carex rufina Drejer (Cyperaceae), a west-arctic, perennial sedge restricted to wet, peaty, sandy or gravelly substrates in middle and low arctic-alpine, late snowbeds or pond marginals. It forms flat, dense tufts of leaves, among which the culms with 2-3 lower female spikes and one bisexual terminal spike are more or less hidden. Although explicit data on its breeding system are lacking, pollination of Cyperaceae is generally wind mediated. Carex rufina reproduces vegetatively by short rhizomes (Hylander 1966), and it is likely to be mainly selffertilizing. It might be locally abundant in mountains in Norway, Sweden, Iceland, and South Greenland, but it is only known from a few stations around Hudson Bay in Canada (Fig. 1). Most sites are found in the oceanic western parts of the southern Scandinavian mountain range, but habitat loss due to drier conditions and species invading from adjacent vegetation has led to population decline the last 30 years, causing $C$. rufina to be listed as near threatened
Fig. 1 AFLP phenotypes identified in C. rufina (star and open circles), and total geographic distribution (black dots: Blondeau 2004; Devold and Scholander 1933; Feilberg 1984; Fredskild 1994; Hultén and Fries 1986; The Icelandic Institute of Natural History, http://vefsja.ni.is/website/ plontuvefsja/). Map in North pole Azimuthal equidistant projection. Inset $\mathrm{KB}$ Westergaard

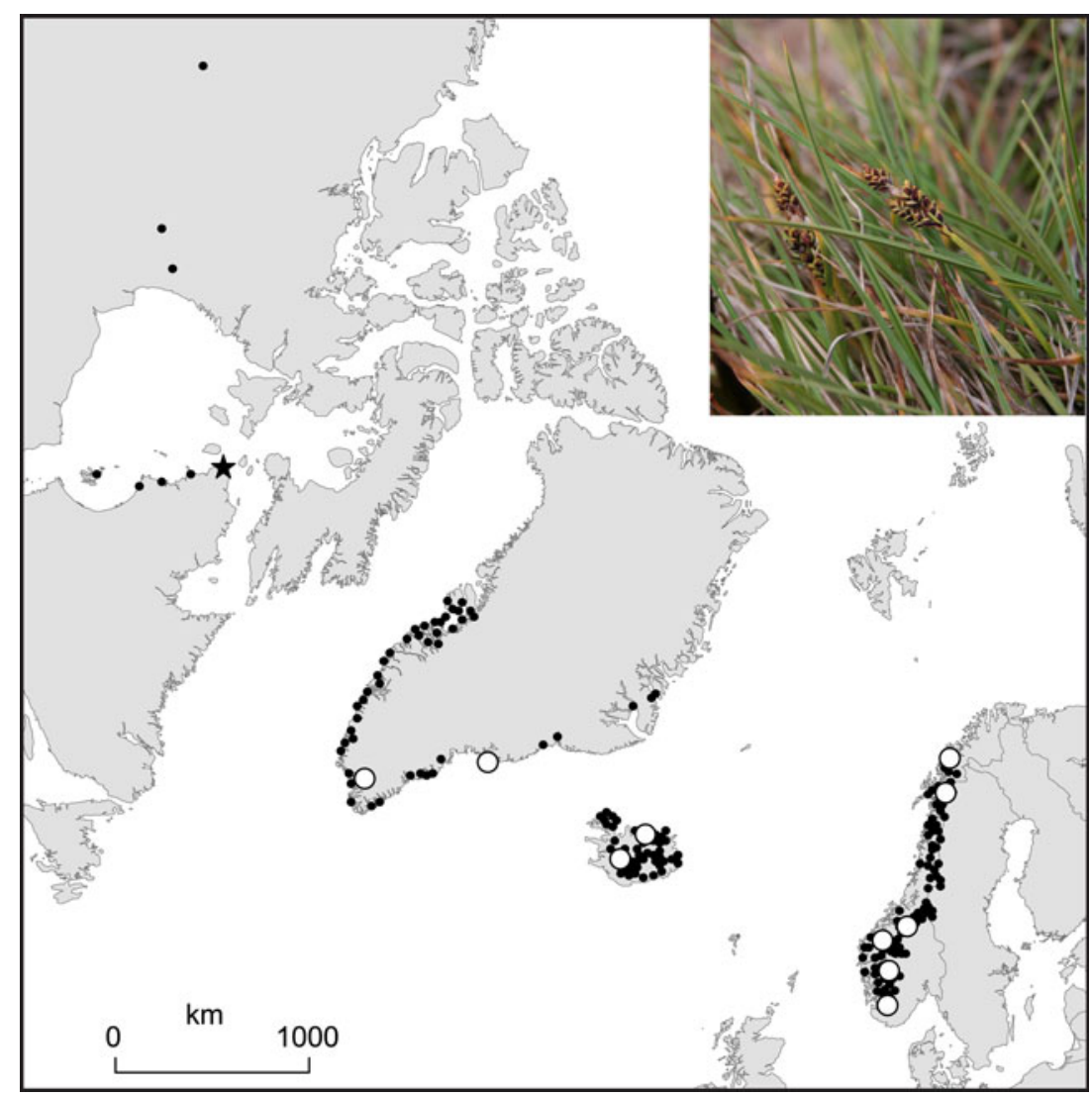


on the Norwegian Red List (www.biodiversity.no). It is challenging to identify management units (MUs) for conservation in little known species. To suggest MUs for C. rufina, we will use genetic tools in combination with available information on population ecology in order to identify genetically distinct and diverse population groups, and assess the level of gene flow.

In a study of amplified fragment length polymorphism (AFLP) variation in North Atlantic species of Carex section Phacocystis, only one AFLP phenotype was found in C. rufina, but this study only included four individuals from two South Norwegian populations (Nakamatte and Lye 2007). Here we use the highly sensitive and reproducible AFLP markers to investigate genetic structure, diversity and relationships among the fragmented populations of $C$. rufina range-wide. In particular, we ask whether these high-resolution markers will reveal more genetic diversity on a range-wide scale. If a pattern of local, distinctive genetic groups are observed, we ask whether they indicate locations of glacial refugia and postglacial migration routes. Further, we aim to provide recommendations for conservation based on levels and patterns of genetic diversity and distinctiveness.

\section{Materials and methods}

A total of 69 individuals from 11 populations of $C$. rufina were sampled in the field, covering most of its range except that we were not able to localize the species in West Greenland (Table 1; Fig. 1). The individuals were sampled as far from each other as possible given the spatial extent of the population, which ranged from a few square decimetres to a few meters, in order to reduce the probability of duplicating genets. If possible, leaf material from ten individuals per population was collected and dried in silica gel. Voucher specimens are deposited at the Botanical Museum, University of Oslo (O), and silica material and DNA extracts are stored in the DNA bank of the National Centre for Biosystematics (NCB), University of Oslo.

The DNA extraction and AFLP analyses followed Westergaard et al. (2011). Because we did not observe any variation in initial tests, we included as many as 48 primer combinations with two or three selective bases for MseI in an extended test, including 4-8 individuals from different geographic regions. However, this extended test did neither reveal any variation. We selected the following primer combinations for full-scale analysis because they yielded the highest number of well-separated fragments (fluorescent dye in parenthesis): EcoRI-AGA (6FAM)-MseICAT, EcoRI-ATG (VIC)-MseI-CTA, and EcoRI-ACC (NED)-MseI-CTG. To test for reproducibility (Bonin et al. 2004), three samples were included in all runs, and eight DNA samples were duplicated and analyzed twice.

\section{Results}

The three primer combinations resulted in a dataset of 122 markers, of which only five $(4.1 \%)$ were polymorphic. Only two AFLP phenotypes were observed: one in the only Canadian population available for analysis, and the other in all Greenlandic, Icelandic, and Norwegian populations. The Canadian phenotype had three private markers, and lacked two markers present in the others. The reproducibility of the data set was complete (100\%). The extremely low level of genetic diversity made further statistical tests unnecessary.

Table 1 Collection information of the investigated populations of C. rufina

\begin{tabular}{|c|c|c|c|c|c|c|}
\hline Pop ID & Geographic origin & Latitude & Longitude & Year & Collector(s)* & $\mathrm{n}$ \\
\hline KW06-61 & Norway, Troms, Troms $\varnothing$, Djupdalen & 69.595 & 19.042 & 2006 & KBW, EB & 9 \\
\hline KW08-1 & Norway, Nordland, Narvik, $\mathrm{N}$ of Forsvatnet & 68.129 & 17.191 & 2008 & KBW, EB & 6 \\
\hline KIF-06-3 & Norway, Sør-Trøndelag, Oppdal, S of Høgvardtjønna & 62.510 & 9.804 & 2006 & KIF & 8 \\
\hline Lye-440 & Norway, Møre og Romsdal, Stranda, Geiranger & 62.033 & 7.283 & 2004 & KAL & 1 \\
\hline AKW-07-1 & Norway, Hordaland, Ulvik, Finse Research Station & 60.605 & 7.501 & 2007 & AKW & 7 \\
\hline Lye-377 & Norway, Vest-Agder, Sirdal, Suleskard & 59.019 & 6.985 & 2004 & KAL & 5 \\
\hline KW07-29 & Iceland, Kjölur, Hvitarvatn & 64.535 & -19.782 & 2007 & KBW, TD & 7 \\
\hline KW07-40 & Iceland, Akureyri, Leirdalsheiði & 65.991 & -18.064 & 2007 & KBW, TD & 5 \\
\hline KW06-42 & Greenland (DK), Narsarsuaq, Blomsterdalen & 61.219 & -45.304 & 2006 & $\mathrm{KIF}, \mathrm{BBF}$ & 8 \\
\hline Kulusuk & Greenland (DK), Kong Christian IX Land, Kulusuk & 65.576 & -37.135 & 2009 & SB, IEBS & 10 \\
\hline $367-07$ & Canada, Quebec, Nunavik, Ivujivik & 62.497 & -78.078 & 2007 & $\mathrm{KIF}, \mathrm{BBF}$ & 3 \\
\hline
\end{tabular}

Pop ID refers to the collection code; $n$ is the number of individuals used in the AFLP analyses

* Collectors: $A K W$ Anders K. Wollan, BBF Bergfrid Bjerkan Flatberg, EB Espen Bakke, $I S$ Idunn Elisabeth Borgen Skjetne, KAL Kåre Arnstein Lye, KBW Kristine Bakke Westergaard, KIF Kjell Ivar Flatberg, SB Siri Birkeland, TD Tina Dahl 


\section{Discussion}

Trans-Atlantic AFLP uniformity

Surprisingly, we only observed a single, trans-Atlantic AFLP phenotype in the highly disjunct populations of C. rufina from Norway, Iceland, and southern Greenland. The Canadian population only had a slightly different phenotype (4.1\%; Fig. 1). Although technical limitations of the AFLP procedure may hamper detection of genetic diversity, even if we tested 48 different primer combinations to detect potential variation, it is obvious that $C$. rufina contains much less genetic variation than most other arctic-alpine plants studied so far (e.g., Alsos et al. 2007; Brochmann and Brysting 2008). The lack of genetic diversity in C. rufina can have historical as well as ecological causes.

Although slight, the genetic difference between the Canadian population and the remaining Atlantic populations is based on several private markers, and probably indicate that these two groups originate from separate glacial refugia. Recent analyses of two other west-arctic species, Arenaria humifusa and Sagina caespitosa, revealed higher levels of genetic diversity and a distinct separation into one East and one West Atlantic group, suggesting survival in glacial refugia on both sides of the North Atlantic ocean throughout the last glaciation (Westergaard et al. 2011). Based on their patterns of genetic diversity and distinctiveness, A. humifusa and $S$. caespitosa were considered most likely to have persisted throughout the last glaciation in situ in the East Atlantic region. Although the lack of AFLP variation in C. rufina precludes further elaboration on refugial regions and postglacial dispersal routes, the observed pattern is consistent with in situ glacial survival also of this species, probably in Scandinavia. The dynamics of the ice sheets may have made extensive and suitable snowbeds available in Scandinavia during most of the last glacial period (Westergaard et al. 2011, and references therein). Alternatively, C. rufina may have occurred south of the North European ice sheets during the last glaciation, where an extensive glacial fossil record exists of another, although less specialized snowbed species (Salix herbacea; Alsos et al. 2009).

Little information is available on the reproductive biology of $C$. rufina, but long-living perennials able to reproduce clonally may buffer the genetic effects of fragmentation by delaying the time between generations (Honnay and Bossuyt 2005, and references therein). Studies of other autogamous pioneer species that typically occur in snowbeds have also reported low or absent genetic diversity across highly disjunctive ranges in the North Atlantic region. Virtually no detectable AFLP variation was found in Ranunculus pygmaeus (Schönswetter et al. 2006) and Saxifraga stellaris (Westergaard et al. 2008), or in the partly selfing Arabis alpina (Ehrich et al. 2007), and no isozyme variation was found in the clonal and selfing grass Vahlodea atropurpurea (Haraldsen et al. 1991). During the final stages of the last glaciation, when the large ice sheets retracted and exposed open habitats, such snowbed species probably had favourable conditions. They may have acted as 'invasive' species, which are well known to undergo genetic bottlenecks leading to low or absent genetic diversity in invaded areas (Le Roux et al. 2007). Thus, a plausible explanation for the low levels of genetic diversity in C. rufina and other snowbed species is rapid, leading-edge colonization of the North Atlantic region from strongly bottlenecked source populations. For C. rufina, the lack of genetic variation may have been maintained by a pronounced local clonality.

Dispersal and implications for conservation

Our results suggest that although $C$. rufina has been able to disperse post-glacially across the North Atlantic region, it relies heavily on propagation by local clonal growth. In addition to genetic drift, the low variation in AFLP markers and morphology (Hultén 1958; Nakamatte and Lye 2007) can possibly be ascribed to selection for adaptation to a very narrow niche. Due to the contemporary limitations of suitable habitat, $C$. rufina has restricted opportunities to expand its range and population sizes, which again renders it threatened by ongoing and future habitat loss.

Based on the assumed lack of contemporary gene flow among geographically separated populations and limited genetic diversity, the Canadian population could be treated as a separate management unit (Waples and Gaggiotti 2006), and the populations in southern Greenland, Iceland, and Norway as another. However, the latter mentioned populations are distributed along a considerable geographic gradient. Even if we only observed a single AFLP phenotype and little morphological variation along this gradient, we cannot exclude that adaptive genetic differences exist due to varying local selection (Höglund 2009). Habitat availability is probably the main limiting factor for C. rufina, and an appropriate focus of management would be to preserve as many as possible of the currently occupied habitats. This is particularly important where populations of $C$. rufina may be affected, or even exterminated, by flooding or habitat loss caused by water regulation schemes, a consequence which has been reported from northern Norway (Granmo 1993).

Acknowledgments We thank our colleagues for help with providing plant samples, and the authorities in various regions for permits to collect samples. The study was supported by grant $170952 / \mathrm{V} 40$ to CB from the Research Council of Norway, and an additional grant to KBW from the Roald Amundsen Centre for Arctic Research (project 200507652). Two anonymous referees contributed to the final version of the manuscript. 
Open Access This article is distributed under the terms of the Creative Commons Attribution Noncommercial License which permits any noncommercial use, distribution, and reproduction in any medium, provided the original author(s) and source are credited.

\section{References}

ACIA (2005) Arctic climate impact assessment: scientific report. Cambridge University Press, Cambridge

Alsos IG, Eidesen PB, Ehrich D, Skrede I, Westergaard K, Jacobsen GH, Landvik JY, Taberlet P, Brochmann C (2007) Frequent long-distance plant colonization in the changing Arctic. Science 316:1606-1609

Alsos IG, Alm T, Normand S, Brochmann C (2009) Past and future range shifts and loss of diversity in dwarf willow (Salix herbacea L.) inferred from genetics, fossils and modelling. Global Ecol Biogeogr 18:223-239

Björk RG, Molau U (2007) Ecology of alpine snowbeds and the impact of global change. Arctic Antarc Alpine Res 39:34-43

Blondeau M (2004) Atlas of plants of the Nunavik villages. Éditions MultiMondes, Quebec

Bonin A, Bellemain E, Eidesen PB, Pompanon F, Brochmann C, Taberlet $P$ (2004) How to track and assess genotyping errors in population genetics studies. Mol Ecol 13:3261-3273

Brochmann C, Brysting AK (2008) The Arctic-an evolutionary freezer? Plant Ecol Divers 1:181-195

Brochmann C, Gabrielsen TM, Nordal I, Landvik J, Elven R (2003) Glacial survival or tabula rasa? The history of North Atlantic biota revisited. Taxon 52:417-450

Devold J, Scholander PF (1933) Flowering plants and ferns of Southeast Greenland. Skrifter om Svalbard og Ishavet vol 56. Det kongelige departement for handel, sjøfart, industri, håndverk og fiskeri, Oslo

Ehrich D, Gaudeul M, Assefa A, Koch MA, Mummenhoff K, Nemomissa S, Consortium Intrabiodiv, Brochmann C (2007) Genetic consequences of Pleistocene range shifts: contrast between the Arctic, the Alps and the East African mountains. Mol Ecol 16:2542-2559

Eidesen PB, Alsos IG, Popp M, Stensrud O, Suda J, Brochmann C (2007) Nuclear vs. plastid data: complex pleistocene history of a circumpolar key species. Mol Ecol 16:3902-3925

Feilberg J (1984) A phytogeographical study of South Greenland. Vascular plants. Meddel Grønland Biosci 15:1-70

Frankham R, Ballou JD, Briscoe DA (2010) Introduction to conservation genetics, 2nd edn. Cambridge University Press, Cambridge

Fredskild B (1994) A phytogeographical study of the vascular plant of West Greenland $\left(62^{\circ} 20^{\prime}-74^{\circ} 00^{\prime}\right)$. Meddel Grønland Biosci 45:1-157

Gjærevoll O (1956) The plant communities of the Scandinavian alpine snow-beds. Det Kgl. Norske Videnskabers Selskabs Skrifter 1956 nr 1. Aktietrykkeriet, Trondheim

Granmo A (1993) Virkninger av vassdragsregulering på vegetasjon og landskap i Skjomenfjellene ved Narvik. Tromura Naturvitenskap. Troms $\varnothing$ Museum, Troms $\varnothing$
Haraldsen KB, Ødegaard M, Nordal I (1991) Variation in the amphiAtlantic plant Vahlodea atropurpurea (Poaceae). J Biogeogr $18: 311-320$

Hewitt GM (1999) Post-glacial re-colonization of European biota. Biol J Linn Soc 68:87-112

Höglund J (2009) Evolutionary conservation genetics. Oxford University Press, Oxford

Honnay O, Bossuyt B (2005) Prolonged clonal growth: escape route or route to extinction? Oikos 108:427-432

Hultén E (1958) The amphi-Atlantic plants and their phytogeographical connections. Kungliga svenska vetenskapsakademiens handlingar, vol 4. Almqvist \& Wiksell, Stockholm

Hultén E, Fries M (1986) Atlas of North European vascular plants north of the tropic of cancer. Koeltz Scientific Books, Königstein

Hylander N (1966) Nordisk kärlväxtflora II. Omfattande Sveriges, Norges, Danmarks, Östfennoskandias, Islands och Färöarnas kärlkryptogamer och fanerogamer. Almqvist \& Wiksell, Stockholm

Le Roux JJ, Wieczorek AM, Wright MG, Tran CT (2007) Supergenotype: global monoclonality defies the odds of nature. PLOS ONE 2:e590

Nakamatte E, Lye KA (2007) AFLP-based differentiation in North Atlantic species of Carex sect. Phacocystis. Nord J Bot $25: 318-328$

Nathan R (2006) Long-distance dispersal of plants. Science 313:786-788

Nordal I (1987) Tabula rasa after all? Botanical evidence for ice-free refugia in Scandinavia reviewed. J Biogeogr 14:377-388

Scheffknecht S, Dullinger S, Grabherr G, Hulber K (2007) Mating systems of snowbed plant species of the northeastern Calcareous Alps of Austria. Acta Oecol Int J Ecol 31:203-209

Schöb C, Kammer PM, Choler P, Veit H (2009) Small-scale plant species distribution in snowbeds and its sensitivity to climate change. Plant Ecol 200:91-104

Schönswetter P, Paun O, Tribsch A, Niklfeld H (2003) Out of the Alps: colonization of northern Europe by East Alpine populations of the glacier buttercup Ranunculus glacialis L. (Ranunculaceae). Mol Ecol 12:3373-3381

Schönswetter P, Popp M, Brochmann C (2006) Rare arctic-alpine plants of the European Alps have different immigration histories: the snowbed species Minuartia biflora and Ranunculus pygmaeus. Mol Ecol 15:709-720

Theurillat JP, Guisan A (2001) Potential impact of climate change on vegetation in the European Alps: A review. Climatic Change 50:77-109

Waples RS, Gaggiotti O (2006) What is a population? An empirical evaluation of some genetic methods for identifying the number of gene pools and their degree of connectivity. Mol Ecol 15:1419-1439

Westergaard KB, Alsos IG, Ehrich D, Eidesen PB, Hollingsworth PM, Brochmann C (2008) Genetic diversity and distinctiveness in Scottish alpine plants. Plant Ecol Divers 1:329-338

Westergaard KB, Alsos IG, Popp M, Engelskjøn T, Flatberg KI, Brochmann C (2011) Glacial survival may matter after all: nunatak signatures in the rare European populations of two westarctic species. Mol Ecol 20:376-393 